Original Article

\title{
Molecular epidemiology of Clostridioides difficile and risk factors for the detection of toxin gene-positive strains
}

\author{
Yuya Okada, Norihito Kaku*, Kosuke Kosai, Naoki Uno, Yoshitomo Morinaga, \\ Hiroo Hasegawa, Katsunori Yanagihara \\ Department of Laboratory Medicine, Nagasaki University Graduate School of Biomedical Sciences, Nagasaki, Japan
}

\section{A R T I C L E I N F O}

\section{Article history:}

Received 2 October 2018

Received in revised form

21 November 2018

Accepted 12 December 2018

Available online 12 January 2019

\section{Keywords:}

Clostridioides difficile

Molecular epidemiology

Risk factor

Toxin gene

\begin{abstract}
A B S T R A C T
In this study, we investigated all Clostridioides difficile strains isolated from stool samples in Nagasaki University Hospital between January 2012 and December 2014. Toxin genes ( $t c d A, t c d B$ and $c d t A / c d t B$ ) were analyzed for multiplex PCR in a total of 213 strains. In the toxin gene-positive strain, PCR ribotyping was conducted using capillary gel electrophoresis-based PCR and the Webribo database. Patients' backgrounds were analyzed by departments, disorders, antimicrobials, and clinical dates. The positive rates of $t c d A, t c d B$, and $c d t A / c d t B$ genes were $62.9 \%, 63.4 \%$, and $2.8 \%$, respectively. The most frequent PCR ribotype was 047 (14.1\%), followed by $014 / 0$ (11.1\%) and 002/0 (8.2\%). In univariate analysis, the risk factors for the detection of toxin gene-positive strains in patients were older age $(p=0.0036)$, over $\geq 65$ years old $(p=0.0175)$, the patients hospitalized at Department of Digestive Surgery $(P=0.0059)$, higher CRP level $(P=0.0395)$, and lower albumin level $(p=0.0014)$. In the multivariate analysis, the risk factor for detection of toxin gene-positive strains was the patients hospitalized at Department of Digestive Surgery (OR; 4.62, 95\% CI; $1.18-18.0, p=0.0274)$. In this study, the percentage of toxin gene-positive and $c d t A / c d t B$ gene-positive strains was almost the same as that reported in previous studies, but the ribotype was different. In addition, we revealed that the risk factor associated with the detection of toxin genepositive strains was the patients hospitalized at Department of digestive surgery.
\end{abstract}

(c) 2018 Japanese Society of Chemotherapy and The Japanese Association for Infectious Diseases. Published by Elsevier Ltd. All rights reserved.

\section{Introduction}

Clostridioides difficile is a gram-positive anaerobic bacterium and a causative pathogen of antibiotic-associated diarrhea (AAC) [1]. In C. difficile infections (CDIs), toxin A and B play important roles [2,3]. Both toxins have cytotoxic activities and induce the release of various immunomodulatory mediators from epithelial cells, phagocytes, and mast cells [2]. Recently, the spread of binary toxin (CDT)-producing strains has raised a major concern in the United States and Europe. CDT-producing strains are highly resistant to fluoroquinolones and increase mortality [4-6]. In European Society of Clinical Microbiology and Infectious Diseases (ESCMID) guideline for the diagnosis of CDI, glutamate dehydrogenase (GDH) screening test, toxin A and toxin B EIA testing, and nucleic acid amplification tests (NAATs) for toxin genes are recommended [7].

\footnotetext{
* Corresponding author. Department of Laboratory Medicine, Nagasaki University Graduate School of Biomedical Sciences, 1-7-1 Sakamoto, Nagasaki 852-8501, Japan. E-mail address: kaku-ngs@umin.ac.jp (N. Kaku).
}

Although the sensitivities of NAATs were higher than that of the EIA test, it was difficult to conduct NAATs on all specimens in routine examinations, because of the high cost and labor involved. The first European Society of Clinical Microbiology and Infectious Diseases (ESCMID) guideline recommend a two-step algorithm: first, samples should be analyzed by EIA testing; if the result is positive for GDH and negative for toxin $A / B$, samples are then analyzed by NAATs [7]. Recently, the fully automated molecular test (FAMT) has been developed, making it easier to perform NAATs $[8,9]$ and allowing for the detection of CDT. Many hospitals are expected to implement the NAATs including FAMT, but there have been few molecular epidemiological studies of $C$. difficile and CDT in Japan [10-12].

In this study, we investigated the molecular epidemiology of C. difficile. Additionally, to clarify the patients who were recommended for performance of the NAATs, we investigated and compared the patients' backgrounds between toxin-positive and -negative $C$. difficile to clarify the risk factors for CDI. 


\section{Materials and methods}

\subsection{Study design and sample collection}

This study was conducted between January 2012 and December 2014. This study was approved by the ethics committee of Nagasaki University Hospital (13062425). We collected C. difficile isolated from stool samples between January 2012 and December 2014 in Nagasaki University Hospital. To avoid duplicates, only the first isolate from each patient was collected.

The patient background information, such as age, gender, length of hospitalization, underlying diseases, history of surgery within 90 days before submission of stool sample, length of hospitalization before submission of stool sample, oral and intravenous administration of antimicrobial agents, use of proton pump inhibitors (PPIs), and use of histamine-2 receptor antagonists (H2 blockers) within 60 days before submission of stool sample, CDI symptoms associated with CDI, and mortality rate were analyzed. We defined administration of metronidazole and oral vancomycin after submission of stool sample as CDI treatment. Because we did not evaluate the Bristol scale in the laboratory during the study period, we investigated the development of diarrhea, based on medical record. We also investigated the laboratory data for white blood cell count $\left(\times 10^{3} / \mu \mathrm{l}\right)$, red blood cell count $\left(\times 10^{6} / \mu \mathrm{l}\right)$, C-reactive protein $(\mathrm{CRP})(\mathrm{mg} / \mathrm{dl})$, blood urea nitrogen $(\mathrm{BUN})(\mathrm{mg} / \mathrm{dl})$, serum creatinine $(\mathrm{mg} / \mathrm{dl})$, uric acid (UA) (mg/dl), total protein (TP) (g/dl), albumin (g/ $\mathrm{dl}$ ), and lactate dehydrogenase (LD) (U/l) at one day before and after submission of the stool sample.

\subsection{Genetic analysis}

In this study, we used the ATCC9689 strain as a positive control. We inoculated all $C$. difficile strains with cycloserine-cefoxitin mannitol agar (CCMA; Nissui Pharmaceutical Co., Ltd., Japan). The plates were incubated at $37{ }^{\circ} \mathrm{C}$ for $48-72 \mathrm{~h}$ under anaerobic conditions. Bacterial DNA was extracted by using Achromopeptidase solution (Wako Chemical Co., Ltd., Osaka, Japan), 10\% Chelex-100 (Bio-Rad Laboratories, Hercules, CA, USA), and the boiling method [13]. We confirmed the genes for toxins ( $t c d A$ and $t c d B$ ), CDT ( $c d t A$ and $c d t B$ ), and $16 \mathrm{~S}$ rRNA by PCR as previously described [14]. The $16 \mathrm{~S}$ rRNA primers were as follows: forward 8UA, 5'-AGAGTTTGATCMTGGCTCAG-3'; and reverse 1458B, 5'-TACGGTTACCTTGTTACGAC-3' [15].

PCR ribotyping was evaluated by capillary gel electrophoresisbased PCR, which was performed according to the protocol of a previous study [16]. In this method, we used the Applied
Biosystems 3130 genetic analyzer with POP7 polymer (Applied Biosystems, Foster City, CA, USA) and GeneScan-1200Liz size standard (Applied Biosystems). The size of each peak was determined using Peak Scanner software v1.0 (Life Technologies, Carlsbad, CA), and PCR ribotypes were determined by the Webribo database of the Austrian Agency for Health and Food Safety (https://webribo.ages.at).

We defined a following situation as outbreak, based on the notification from Regional Medical Care Planning Devision, Healthy Policy Bureau, Ministry of Health, Labor and Welfare, Japan (December 19, 2014): same PCR ribotype strain was isolated from three or more patients hospitalized in same ward within 4 weeks.

\subsection{Statistical analysis}

The statistical software used in this study was JMP Pro 10.0.2 (SAS Institute Inc, Cary NC, USA). Continuous variables were compared using the Student's $t$-test. The chi-square was used to compare categorical variables. Variables with a $P$ value less than 0.20 according to the univariate analysis were considered for inclusion in the forward stepwise multivariate logistic regression analysis.

\section{Results}

\subsection{Genetic analysis}

C. difficile strains were isolated from a total of 213 (122 men and 91 women) patients during the study period (Fig. 1). The positive rates of $t c d A, t c d B$, and CDT genes were $62.9 \%(\mathrm{n}=134), 63.4 \%$ $(\mathrm{n}=135)$, and $2.8 \%(\mathrm{n}=6)$, respectively. We defined strains harboring the $t c d A$ and/or $t c d B$ genes as toxin gene-positive strains. Among the toxin gene-positive strains, the positive rate of CDT gene was $4.4 \%$.

PCR ribotyping was performed on toxin gene-positive strains (Table 1). The most frequent PCR ribotype was the 047 strain (14.1\%), followed by 014/0 (11.1\%), 002/0 (8.2\%), 020 (6.7\%), and 018 (4.4\%). The PCR ribotypes of CDT-positive strains were 016 (two strains), 131 (three strains), and 413 (one strain). There was no outbreak of each PCR ribotype in this study.

\subsection{Comparison of toxin gens-positive and -negative strains}

The patient backgrounds with toxin gene-positive and -negative strains are shown in Table 2. The average age of the patients was significantly higher in patients with toxin gene-positive strains

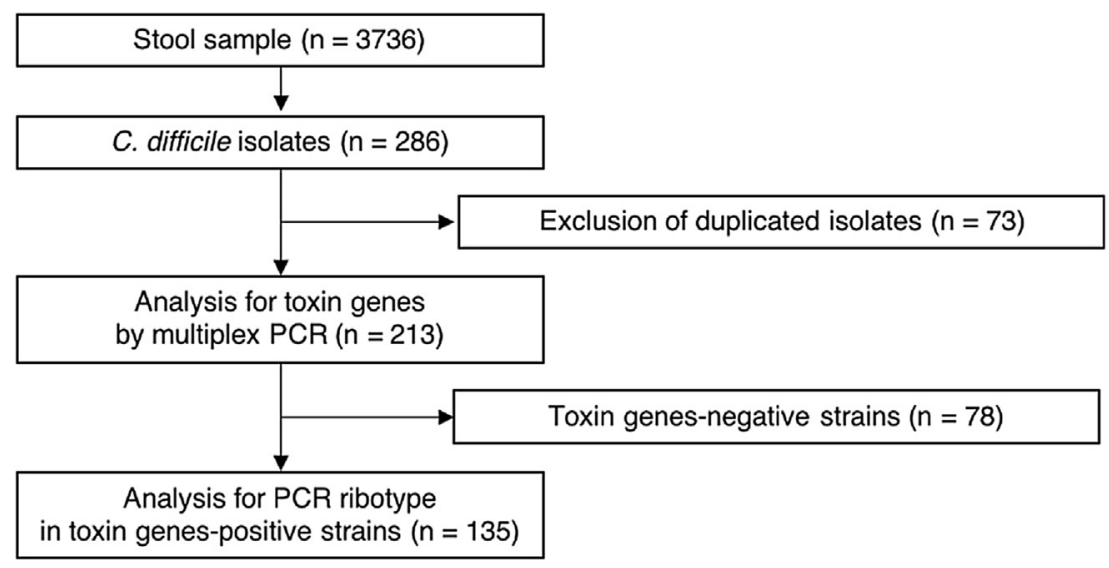

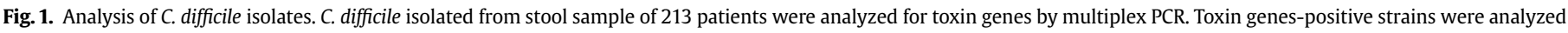
for PCR ribotype $(\mathrm{n}=135)$. 
Table 1

PCR ribotype of toxin genes-positive strains.

\begin{tabular}{lll}
\hline Ribotype & $(\mathrm{N})$ & $(\%)$ \\
\hline 047 & 19 & 14.1 \\
$014 / 0$ & 15 & 11.1 \\
$002 / 0$ & 11 & 8.1 \\
020 & 9 & 6.7 \\
018 & 6 & 4.4 \\
043 & 5 & 3.7 \\
449 & 5 & 3.7 \\
076 & 4 & 3.0 \\
209 & 4 & 3.0 \\
001 & 3 & 2.2 \\
012 & 3 & 2.2 \\
056 & 3 & 2.2 \\
153 & 3 & 2.2 \\
638 & 3 & 2.2 \\
015 & 2 & 1.5 \\
046 & 2 & 1.5 \\
131 & 2 & 1.5 \\
404 & 2 & 1.5 \\
496 & 2 & 1.5 \\
541 & 2 & 1.5 \\
660 & 2 & 1.5 \\
$014 / 5$ & 2 & 1.5 \\
Other & 26 & 19.3 \\
\hline
\end{tabular}

Other: less than $1 \%$.

(54.2 years) than in those with toxin gene-negative strains (42.4) $(p=0.0034)$. There were significant differences between the two groups in terms of the inpatient department. The percentage of patients with toxin gene-positive strains who were hospitalized at the Department of Pediatrics was significantly lower in patients with toxin-positive gene (25 patients, 15.6\%) than in those with toxin gene-negative strains (25 patients, $32.1 \%)(p=0.0055)$. In contrast, the percentage of patients with toxin gene-positive strains who were hospitalized at the Department of Digestive Surgery was significantly higher than in patients with toxin-positive gene strains (27 patients, $20.0 \%$ ) than in those with toxin gene-negative strains (four patients, $5.2 \%)(p=0.0015)$. When analyzing the laboratory data, the serum albumin levels in patients with toxin genepositive strains was significantly lower $(3.0 \pm 0.7 \mathrm{~g} / \mathrm{dl})$ than in those with toxin gene-negative strains $(3.3 \pm 0.7 \mathrm{~g} / \mathrm{dl})(p=0.0017)$.

Administration of antimicrobials, PPIs, and $\mathrm{H} 2$ blockers and antimicrobial agents is summarized in Table 3. The PPIs, $\mathrm{H}_{2}$ blockers, and antimicrobial agents were administered to 84 patients (39.4\%), 15 patients (7.0\%), and 157 patients (70.5\%), respectively. The percentage of those administered with macrolides was significantly higher in the patients with toxin gene-positive strains (seven patients, 5.2\%) than in those with gene-negative strains (0 patients, $0.0 \%)(p=0.0107)$.

\subsection{Risk factor for detection of toxin gene-positive strains}

We compared the background of the patients with toxin genepositive and -negative strains by univariate and multivariate analyses to clarify the risk factors for the detection of toxin genepositive strains (Table 4). In the univariate analysis, the risk factors for the detection of toxin genes positive-strain were older age (OR, 0.99; 95\% CI, 0.98-1.00; $p=0.0036$ ), over $\geq 65$ years old (OR, 2.03; 95\% CI, 1.13-3.63; $p=0.0175$ ), patients hospitalized at the Department of Digestive Surgery (OR, 4.63; 95\% CI, 1.55-13.8; $p=0.0059$ ), higher CRP level (OR, 0.94; 95\% CI, 0.89-1.00;

Table 2

Comparison of the patient background between the patients toxin genes-positive and negative strains.

\begin{tabular}{|c|c|c|c|c|}
\hline Background & Total $(\mathrm{n}=213)$ & $\begin{array}{l}\text { Patients with toxin } \\
\text { genes-positive strain }(n=135)\end{array}$ & $\begin{array}{l}\text { Patients with toxin } \\
\text { genes-negative strain }(n=78)\end{array}$ & $P$ value \\
\hline Age & $49.9 \pm 28.4$ & $54.2 \pm 26.5$ & $42.4 \pm 29.9$ & 0.0034 \\
\hline$<15$ years old & $49(23.0 \%)$ & $23(17.0 \%)$ & $26(33.3 \%)$ & 0.0072 \\
\hline$\geq 65$ years old & $91(42.7 \%)$ & $66(48.9 \%)$ & $25(32.0 \%)$ & 0.0159 \\
\hline Sex (male \%) & $122(57.3 \%)$ & $80(59.3 \%)$ & $42(53.8 \%)$ & 0.4422 \\
\hline Length of hospitalization (day) & $32.3 \pm 55.8$ & $33.2 \pm 60.2$ & $30.6 \pm 47.2$ & 0.9466 \\
\hline Diarrhea (\%) & $128(60.1 \%)$ & $83(61.5 \%)$ & $45(57.7 \%)$ & 0.5869 \\
\hline Abdominal tenderness & $59(27.7 \%)$ & $39(28.9 \%)$ & $20(25.6 \%)$ & 0.6086 \\
\hline Temperature $\left(\geq 38.5^{\circ} \mathrm{C}\right)$ & 49 (23.0\%) & $29(21.5 \%)$ & $20(25.6 \%)$ & 0.4893 \\
\hline Previous surgery within 90 days & $36(16.9 \%)$ & $25(18.6 \%)$ & $11(14.1 \%)$ & 0.4023 \\
\hline Mortality within 90 days & $24(11.3 \%)$ & $15(11.1 \%)$ & $9(11.5 \%)$ & 0.9244 \\
\hline $\begin{array}{l}\text { Treatment with CDI (vancomycin } \\
\quad \text { or metronidazole) }\end{array}$ & $44(20.7 \%)$ & $33(24.4 \%)$ & $11(14.1 \%)$ & 0.0663 \\
\hline \multicolumn{5}{|l|}{ Department } \\
\hline Hematology & $47(22.1 \%)$ & $30(22.2 \%)$ & $17(21.8 \%)$ & 0.9422 \\
\hline Pediatrics & $46(21.6 \%)$ & $21(15.6 \%)$ & $25(32.1 \%)$ & 0.0055 \\
\hline Gastroenterology & $44(20.7 \%)$ & $28(20.7 \%)$ & $16(20.5 \%)$ & 0.9684 \\
\hline Digestive Surgery & $31(14.6 \%)$ & $27(20.0 \%)$ & $4(5.2 \%)$ & 0.0015 \\
\hline Respiratory medicine & $11(5.2 \%)$ & $9(6.7 \%)$ & $2(2.6 \%)$ & 0.1700 \\
\hline Anesthesiology & $7(3.3 \%)$ & $4(3.0 \%)$ & $3(3.9 \%)$ & 0.7302 \\
\hline \multicolumn{5}{|l|}{ Disorder } \\
\hline Hematology & $54(25.4 \%)$ & $33(24.4 \%)$ & $21(26.9 \%)$ & 0.6895 \\
\hline Liver & $41(19.2 \%)$ & $26(19.2 \%)$ & $15(19.2 \%)$ & 0.9959 \\
\hline Kidney & $12(5.6 \%)$ & $7(5.2 \%)$ & $5(6.4 \%)$ & 0.7110 \\
\hline Intestinal diseases & $27(12.7 \%)$ & $21(15.7 \%)$ & $6(7.7 \%)$ & 0.0858 \\
\hline Cardiac & $12(5.6 \%)$ & $9(6.7 \%)$ & $3(3.9 \%)$ & 0.3767 \\
\hline \multicolumn{5}{|l|}{ Laboratory data } \\
\hline White Blood Cell $\left(\times 10^{3} / \mu \mathrm{l}\right)$ & $7.5 \pm 6.6$ & $7.4 \pm 6.2$ & $7.7 \pm 7.4$ & 0.9546 \\
\hline Red Blood Cell $\left(\times 10^{6} / \mu \mathrm{l}\right)$ & $3.4 \pm 0.8$ & $3.4 \pm 0.7$ & $3.5 \pm 0.8$ & 0.3977 \\
\hline C-reactive protein (mg/dl) & $5.1 \pm 6.1$ & $5.8 \pm 6.5$ & $3.9 \pm 5.1$ & 0.0565 \\
\hline Blood urea nitrogen $(\mathrm{mg} / \mathrm{dl})$ & $19.1 \pm 15.0$ & $19.8 \pm 16.4$ & $17.8 \pm 11.9$ & 0.5033 \\
\hline Serum creatinine $(\mathrm{mg} / \mathrm{dl})$ & $0.9 \pm 1.1$ & $1.0 \pm 1.0$ & $0.9 \pm 1.3$ & 0.0659 \\
\hline Uric acid (mg/dl) & $4.5 \pm 2.3$ & $4.8 \pm 2.6$ & $4.2 \pm 1.7$ & 0.6126 \\
\hline Total protein $(\mathrm{g} / \mathrm{dl})$ & $6.2 \pm 1.0$ & $6.2 \pm 1.0$ & $6.4 \pm 0.9$ & 0.2012 \\
\hline Albumin $(\mathrm{g} / \mathrm{dl})$ & $3.1 \pm 0.7$ & $3.0 \pm 0.7$ & $3.3 \pm 0.7$ & 0.0017 \\
\hline Lactate dehydrogenase (U/l) & $246.9 \pm 160.6$ & $244.0 \pm 179.9$ & $252.5 \pm 116.2$ & 0.1717 \\
\hline
\end{tabular}


Table 3

Comparison of administration of PPI, H2 blocker and antimicrobial agents between the patients with toxin genes-positive and negative strains.

\begin{tabular}{|c|c|c|c|c|}
\hline Variable & Total $(\mathrm{n}=213)$ & $\begin{array}{l}\text { Patients with toxin } \\
\text { genes-positive strain }(n=135)\end{array}$ & $\begin{array}{l}\text { Patients with toxin } \\
\text { genes-negative strain }(n=78)\end{array}$ & $P$ value \\
\hline PPIs & $84(39.4 \%)$ & $54(40.0 \%)$ & $30(38.5 \%)$ & 0.8247 \\
\hline H2 blocker & $15(7.0 \%)$ & $9(6.7 \%)$ & $6(7.7 \%)$ & 0.7793 \\
\hline $\begin{array}{l}\text { Administration of antimicrobial } \\
\text { agents within } 60 \text { days }\end{array}$ & $157(73.7 \%)$ & $102(75.6 \%)$ & $55(70.5 \%)$ & 0.4288 \\
\hline Penicillin & $49(23.0 \%)$ & $31(23.0 \%)$ & $18(23.1 \%)$ & 0.9848 \\
\hline Cephalosporin & $81(38.0 \%)$ & $51(37.8 \%)$ & $30(38.5 \%)$ & 0.9211 \\
\hline 1st generation Cephalosporin & $17(8.0 \%)$ & $12(8.9 \%)$ & $5(6.4 \%)$ & 0.5139 \\
\hline 2nd generation Cephalosporin & $7(3.3 \%)$ & $3(2.2 \%)$ & $4(5.1 \%)$ & 0.2625 \\
\hline 3rd generation Cephalosporin & $15(7.0 \%)$ & $12(8.9 \%)$ & $3(3.8 \%)$ & 0.1478 \\
\hline 4th generation Cephalosporin & $48(22.5 \%)$ & $28(20.7 \%)$ & $20(25.6 \%)$ & 0.4124 \\
\hline Carbapenems & $64(30.0 \%)$ & $40(29.6 \%)$ & $24(30.8 \%)$ & 0.8614 \\
\hline Aminoglycoside & $7(3.3 \%)$ & $4(3.0 \%)$ & $3(3.8 \%)$ & 0.7302 \\
\hline Fluoroquinolones & $30(14.1 \%)$ & $20(14.8 \%)$ & $10(12.8 \%)$ & 0.6852 \\
\hline Macrolides & $7(3.3 \%)$ & $7(5.2 \%)$ & $0(0.0 \%)$ & 0.0107 \\
\hline
\end{tabular}

PPI, proton pump inhibitors.

Table 4

Univariate and multivariate analysis of the risk factor for the detection of toxin genes-positive strains.

\begin{tabular}{|c|c|c|c|c|c|c|}
\hline \multirow[t]{2}{*}{ Risk factor } & \multicolumn{3}{|c|}{ Univariate analysis } & \multicolumn{3}{|c|}{ Multivariate analysis } \\
\hline & Odds ratio & $95 \% \mathrm{CI}$ & $P$ value & Odds ratio & $95 \% \mathrm{CI}$ & $P$ value \\
\hline Age & 0.99 & $0.98-1.00$ & 0.0036 & 1.01 & $0.96-1.06$ & 0.7574 \\
\hline$<15$ years old & 0.41 & $0.21-0.79$ & 0.0073 & - & - & - \\
\hline$\geq 65$ years old & 2.03 & $1.13-3.63$ & 0.0175 & 1.67 & $0.44-6.37$ & 0.4495 \\
\hline Department of Pediatrics & 0.39 & $0.20-0.76$ & 0.0056 & - & - & - \\
\hline Department of Digestive Surgery & 4.63 & $1.55-13.8$ & 0.0059 & 4.62 & $1.18-18.0$ & 0.0274 \\
\hline Intestinal diseases & 2.21 & $0.85-5.74$ & 0.1032 & 1.28 & $0.38-4.28$ & 0.6915 \\
\hline C-reaction protein (mg/dl) & 0.94 & $0.89-1.00$ & 0.0395 & 0.97 & $0.91-1.04$ & 0.3974 \\
\hline Albumin $(\mathrm{g} / \mathrm{dl})$ & 2.02 & $1.29-3.14$ & 0.0014 & 1.51 & $0.80-2.84$ & 0.2010 \\
\hline Administration of 3rd generation Cephalosporin within 60 days & 2.44 & $0.67-8.93$ & 0.1478 & 7.22 & $0.85-61.0$ & 0.0694 \\
\hline
\end{tabular}

Multivariate analysis; Predictors with a $P$ value $<0.20$ in the univariate analysis were included in forward stepwise multivariate logistic regression analysis.

$p=0.0395)$, and lower albumin level (OR, 2.02; 95\% CI, 1.29-3.14; $\mathrm{P}=0.0014)$. In the multivariate analysis, the risk factors for the detection of toxin gene-positive strains were patients hospitalized at Department of Digestive Surgery (OR, 4.62; 95\% CI, 1.18-18.0; $p=0.0274)$.

\subsection{Characteristics of the patients with CDT gene-positive strains}

CDT gene-positive strains were cultured from 6 patients ( 3 men and 3 women). The age range was $5-84$ years, and the patients under 18 years included 2 patients. All patients had diarrhea, 3 had temperatures of over $38.5^{\circ} \mathrm{C}$, and the white blood cell count was high only in one case $(29,700 / \mu \mathrm{l})$. There were no severe cases, such as pseudomembranous enteritis, in the 6 patients. Treatment with CDI (vancomycin or metronidazole) was administered only in 3 cases. All cases were cured from CDI.

\section{Discussion}

This study revealed the molecular epidemiology of $C$. difficile and risk factors for the detection of toxin gene-positive strains. In a previous Japanese study, the percentage of toxin gene-positive strains and CDT gene-positive strains was $73 \%$ and $2 \%$, respectively [10]. In other Japanese study, CDT-gene positive strains was $5 \%$ [17]. In comparison with the previous studies, the percentage of toxin gene-positive strains that was lower than that of CDT genepositive strains was nearly the same in this study. The lower percentage of toxin gene-positive strain was caused by a difference in collection of samples. The previous report investigated suspected CDI, but in this study, we investigated all strains cultured from stool samples. Therefore, our study involved the patients with colonization of $C$. difficile. The percentage of CDT gene-positive strain in Japan seemed to be lower than that in other countries: the percentage of CDT gene-positive strain in Colombia was $17.5 \%$ [18]; in United Kingdom and Finland, the percentage of CDT genepositive strains was $16.9 \%$ and $37 \%$, respectively $[19,20]$. Additionally, in this study, we did not detect NAP1/027 and 078 strains, which were reported as the causative pathogens of serious and epidemic CDI in Europe and United States [21]. The PCR ribotype of CDT gene-positive strains in this study was 016, 131, and 413.

In this study, we clarified the PCR ribotype in all toxin genepositive strains. The most frequent ribotypes as revealed by PCR for toxin gene-positive strains were $047,014 / 0$, and 020 in this study. In a previous Japanese study, the ribotypes present at a high frequency were strains $018,002,052$, and 369 [22]. In other Japanese study, the ribotypes present at a high frequency was strains 449 [17]. The frequent PCR ribotypes varied by the studies in Japan $[17,22]$. In the United States, the most frequent PCR ribotypes were strains 002, 014-020, 027, and 053-163 [23], but the most frequent PCR ribotypes were different according to area. Other reports from the United States revealed that the most frequent PCR ribotypes in the northeast, southern, midwestern, and western United States were $027,014 / 020,106,001,053$, respectively [24]. We hypothesized that ribotypes differed from area to area, and that it is important to conduct surveillance in each area. Additionally, $42 \%$ of the PCR ribotype strain 047 was detected from the patients at Department of Digestive Surgery in this study, but we did not observe outbreak of the strain. This result was indicating that epidemic ribotypes differed from ward to ward.

We investigated the risk factors for the detection of toxinpositive strains by comparing the characteristics of patients with toxin gene-positive and negative strains. In the univariate analysis, 
there was no significant difference in the administration history of the antimicrobial drugs or the type of antibiotics between the patients with toxin gene-positive and -negative strains. Since the antimicrobial drug administration history was observed at almost the same ratio in both groups, administration of antimicrobial drugs may lead to the colonization of $C$. difficile. In the analysis of laboratory data, the patients with toxin gene-positive strains showed higher CRP and lower albumin levels. However, there were no significant differences in the multivariate analysis. It seems to be difficult to discriminate between the presence or absence of toxin gene-positive strains by using laboratory data. In the multivariate analysis, the risk factors for the detection of toxin gene-positive strains included hospitalized patients at the Department of Digestive Surgery. On the other hand, if $C$. difficile was detected in children, the possibility that they were also positive for toxin genes was relatively low in this study. A previous report revealed that CDI was more frequently caused in solid-organ transplant recipients than in other hospitalized patients, because solid-organ transplant recipients had a several CDI risk factors, such as PPIs, $\mathrm{H}_{2}$ blockers, age greater than 65 years old, severe underlying disease, uremia, gastrointestinal surgery, presence of nasogastric or endotracheal tube, and prolonged hospitalization [25]. The Department of Digestive Surgery in our hospital conducts solid-organ transplants, and it seemed to have had an influence on the higher percentage of toxin gene-positive strains in the Department of Digestive Surgery.

There were some limitations in this study. First, we studied only C. difficile strains cultured from stool samples, and CDIs diagnosed by only enzyme immunoassays were not included in this study. Second, we could not investigate the Bristol scale. If we could investigate the Bristol scale, we would evaluate the association between diarrhea condition and harboring toxin genes including Bristol scale. Third, we did not determine the PCR ribotype of toxin gene-negative strains. The PCR ribotype of the toxin gene-negative strains remained unknown. It is necessary to understand the tendency to colonized $C$. difficile with toxin negative strains. Therefore, further investigations are needed.

\section{Conclusion}

In this study, the percentages of toxin gene-positive and CDT gene-positive strains were almost the same as those reported in previous studies, but the ribotypes differed. In addition, we revealed that the risk factors associated with the detection of toxin gene-positive strains included patients hospitalized at the Department of Digestive Surgery.

\section{Authorship statement}

All authors meet the ICMJE authorship criteria.

\section{Conflicts of interest}

The authors declare no conflicts of interest.

\section{References}

[1] Burke KE, Lamont JT. Clostridium difficile infection: a worldwide disease. Gut Liver 2014;8:1-6. https://doi.org/10.5009/gnl.2014.8.1.1.

[2] Rupnik M, Wilcox MH, Gerding DN. Clostridium difficile infection: new developments in epidemiology and pathogenesis. Nat Rev Microbiol 2009;7: 526-36. https://doi.org/10.1038/nrmicro2164.

[3] Di Bella S, Ascenzi P, Siarakas S, Petrosillo N, di Masi A. Clostridium difficile toxins a and $\mathrm{B}$ : insights into pathogenic properties and extraintestinal effects. Toxins 2016;8:134. https://doi.org/10.3390/toxins8050134.

[4] Labbé AC, Poirier L, MacCannell D, Louie T, Savoie M, Béliveau C, et al. Clostridium difficile infections in a Canadian Tertiary Care Hospital before and during a regional epidemic associated with the BI/NAP1/027 strain.
Antimicrob Agents Chemother 2008;52:3180-7. https://doi.org/10.1128/ AAC.00146-08.

[5] Pépin J, Valiquette L, Alary M, Villemure P, Pelletier A, Forget K. Clostridium difficile-associated diarrhea in a region of Quebec from 1991 to 2003: a changing pattern of disease severity. Can Med Assoc J 2004;171; 466-72.

[6] Swindells J, Brenwald N, Reading N, Oppenheim B. Evaluation of diagnostic tests for Clostridium difficile infection. J Clin Microbiol 2010;48:606-8. https://doi.org/10.1128/JCM.01579-09.

[7] Crobach MJT, Planche T, Eckert C, Barbut F, Terveer EM, Dekkers OM. European society of clinical microbiology and infectious diseases: update of the diagnostic guidance document for Clostridium difficile infection. Clin Microbiol Infect 2016;22:S63-81. https://doi.org/10.1016/j.cmi.2016.03.010.

[8] Kosai K, Iwanaga Y, Akamatsu N, Okada Y, Kaku N. Performance evaluation of the Verigene $(\circledR$ Clostridium difficile nucleic acid test, an automated multiplex molecular testing system for detection of C. difficile toxin. J Infect Chemother 2017;23:674-7. https://doi.org/10.1016/j.jiac.2017.07.002.

[9] Morinaga Y, Akamatsu N, Matsuda J, Tateno H. Diagnostic utilities of a fully automated molecular test for toxigenic Clostridium difficile. J Infect Chemother 2018;24:88-91. https://doi.org/10.1016/j.jiac.2017.09.003.

[10] Kuwata Y, Tanimoto S, Sawabe E, Shima M, Takahashi Y, Ushizawa H, et al. Molecular epidemiology and antimicrobial susceptibility of Clostridium difficile isolated from a university teaching hospital in Japan. Eur J Clin Microbiol Infect Dis 2015;34:763-72. https://doi.org/10.1007/s10096-0142290-9.

[11] Iwashima Y, Nakamura A, Ueda R, Iwashima Y, Nakamura A, Kato $H$, et al. A retrospective study of the epidemiology of Clostridium difficile infection at a University Hospital in Japan: genotypic features of the isolates and clinical characteristics of the patients. J Infect Chemother 2010;16:329-33. https:// doi.org/10.1007/S10156-010-0066-4.

[12] Oka K, Osaki T, Hanawa T, Kurata S, Okazaki M, Manzoku T, et al. Molecular and microbiological characterization of Clostridium difficile isolates from single, relapse, and reinfection cases. J Clin Microbiol 2012;50:915-21. https://doi.org/10.1128/JCM.05588-11.

[13] Kaku N, Yanagihara K, Morinaga Y, Yamada K, Harada Y, Migiyama Y, et al. Influence of antimicrobial regimen on decreased in-hospital mortality of patients with MRSA bacteremia. J Infect Chemother 2014;20:350-5. https:// doi.org/10.1016/j.jiac.2013.12.009.

[14] Persson S, Torpdahl M, Olsen KEP. New multiplex PCR method for the detection of Clostridium difficile toxin. A (tcdA) and toxin. $B(\operatorname{tcdB})$ and the binary toxin (cdtA/cdtB) genes applied to a Danish strain collection. Clin Microbiol Infect 2008;14:1057-64. https://doi.org/10.1111/j.14690691.2008.02092.x.

[15] Funato M, Kaneko H, Ohkusu K, Sasai H, Kubota K, Ohnishi H, et al. Refractory chronic pleurisy caused by Helicobacter equorum-like bacterium in a patient with X-linked agammaglobulinemia. J Clin Microbiol 2011;49:3432-5. https://doi.org/10.1128/JCM.00478-11.

[16] Indra A, Huhulescu S, Schneeweis M, Hasenberger P, Kernbichler S, Fiedler A, et al. Characterization of Clostridium difficile isolates using capillary gel electrophoresis-based PCR ribotyping. J Med Microbiol 2008;57:1377-82. https://doi.org/10.1099/jmm.0.47714-0.

[17] Tokimatsu I, Shigemura K, Osawa K, Kinugawa S, Kitagawa K, Nakanishi N, et al. Molecular epidemiologic study of Clostridium difficile infections in university hospitals: results of a nationwide study in Japan. J Infect Chemother 2018;24:641-7. https://doi.org/10.1016/j.jiac.2018.03.015.

[18] Salazar CL, Reyes C, Atehortua S, Sierra P, Correa MM, Paredes-Sabja D. Molecular, microbiological and clinical characterization of Clostridium difficile isolates from tertiary care hospitals in Colombia. PLoS One 2017;12, e0184689. https://doi.org/10.1371/journal.pone.0184689.

[19] Berry CE, Davies KA, Owens DW, Wilcox MH. Is there a relationship between the presence of the binary toxin genes in Clostridium difficile strains and the severity of C. difficile infection (CDI)? Eur J Clin Microbiol Infect Dis 2017;36: 2405-15. https://doi.org/10.1007/s10096-017-3075-8.

[20] Mentula S, Kotila SM, Lyytikäinen O, Ibrahem S, Ollgren J, Virolainen A. Clostridium difficile infections in Finland, 2008-2015: trends, diagnostics and ribotypes. Eur J Clin Microbiol Infect Dis 2017;36:1939-45. https://doi.org/ 10.1007/s10096-017-3017-5.

[21] Clements AC, Magalhães RJS, Tatem AJ, Paterson DL, Riley TV. Clostridium difficile PCR ribotype 027: assessing the risks of further worldwide spread. Lancet Infect Dis 2010;10:395-404. https://doi.org/10.1016/S1473-3099(10) 70080-3.

[22] Riley TV, Kimura T. The epidemiology of Clostridium difficile infection in Japan: a systematic review. Infect Dis Ther 2018:1-32. https://doi.org/ 10.1007/s40121-018-0186-1.

[23] Rao K, Walk ST, Micic D, Chenoweth E, Deng L, Galecki AT. Procalcitonin Levels associate with severity of Clostridium difficile infection. PLoS One 2013;8, e58265. https://doi.org/10.1371/journal.pone.0058265.

[24] Tickler IA, Goering RV, Whitmore JD, Lynn ANW, Persing DH, Tenover FC. Strain types and antimicrobial resistance patterns of Clostridium difficile isolates from the United States, 2011 to 2013. Antimicrob Agents Chemother 2014;58:4214-8. https://doi.org/10.1128/AAC.02775-13.

[25] Dubberke ER, Burdette SD. Clostridium difficile infections in solid organ transplantation. Am J Transplant 2013;13:42-9. https://doi.org/10.1111/ ajt.12097. 